University of Washington Tacoma

UW Tacoma Digital Commons

Urban Studies Publications

Urban Studies

7-4-2019

\title{
Ruin Tours: Performing and Consuming Decay in Detroit
}

Emma Jean Slager

University of Washington Tacoma, ejslager@uw.edu

Follow this and additional works at: https://digitalcommons.tacoma.uw.edu/urban_pub

\section{Recommended Citation}

Slager, Emma Jean, "Ruin Tours: Performing and Consuming Decay in Detroit" (2019). Urban Studies Publications. 134. https://digitalcommons.tacoma.uw.edu/urban_pub/134

This Article is brought to you for free and open access by the Urban Studies at UW Tacoma Digital Commons. It has been accepted for inclusion in Urban Studies Publications by an authorized administrator of UW Tacoma Digital Commons. 


\title{
Ruin Tours: Performing and Consuming Decay in Detroit
}

\author{
Emma Jean Slager
}

Urban Studies Program, University of Washington Tacoma, Tacoma, USA

University of Washington Tacoma, 1900 Commerce Street, Box 358437, Tacoma, WA 98402, USA

$01-253-692-4798$

ejslager@uw.edu 


\section{Ruin Tours: Performing and Consuming Decay in Detroit}

While urban geographic studies suggest that post-modern landscapes of consumption displace modern landscapes of production through urban redevelopment in the postindustrial city, this study documents practices in which the object of consumption is itself the ruined landscape of production. In the face of economic, demographic, and infrastructural decline, Detroit, Michigan, has become a destination for those interested in viewing the city's iconic ruins. Paradoxically, tours of these ruin sites represent a form of economic development that takes urban decay as its object. Using data collected through participant observation, interviews, and document analysis, this study examines these practices to understand how such tours operate in relation to broader practices of urban redevelopment. It argues that tourism is not only a way of turning the city into a site of consumption, but also a more complicated response to failures of industrial capitalism in which tour operators construct place narratives that suggest different political modes of responding to the city's decline. This is demonstrated by tracing the development of ruin tour programs and examining three representative cases of ruin tours in the city. Examining how local actors respond to urban decline in this way strengthens urban geographic understandings of the post-industrial city and its recapitalization.

Keywords: Detroit; post-industrial city; place politics; tourism; urban redevelopment

\section{Introduction}

In 2004, the satirical news organization The Onion published a news brief about tourism in Detroit. "The Detroit Tourism Board is scaling back the city-sponsored 'Hidden Detroit' program following the deaths of 24 tourists in the past month," stated the fake report. It quoted a tourism official: "The campaign did draw tourists to historically significant places that usually go unnoticed, [...] but ultimately, unfolding the free 'Detroit Off The Beaten Path' maps in the middle of the Purple Gang's old turf was not a good idea." At the time, the idea that Detroit would develop a cultural tour program that took visitors "off the beaten path" seemed an easy joke. Ten years later, however, a visitor to the city would have 
no trouble finding just such a tour. New cultural tours abound, taking tourists by foot, bus, bicycle, or private vehicle to non-traditional tour sites like empty churches and factories that are actively being dismantled for scrap metal. Over a dozen small companies and non-profits offer tours that highlight the city's ruins. From “The Gritty Tour” offered by Segways 2 u to private tours offered by a company called DetroitUrbex, these organizations take thousands of tour-goers to see Detroit's ruins each year.

This article explores these emerging tourism activities, called ruin tours for their attention to sites of abandonment and urban decay. Ruin tourism is a kind of niche cultural tourism that encompasses a range of activities spanning formal, commercial tours to illegal, guided urban exploration. The ruin sites it features are frequently industrial but also include other recently vacated sites, such as theaters, schools, office buildings, and civic buildings. Though it resembles various other practices, I argue that ruin tourism is a distinct phenomenon that warrants investigation for the insights it generates about urban representational politics in the post-industrial city.

Ruin tours differ from cultural heritage tours in that the object of touristic consumption is urban decay itself rather than the decay's antecedent; tourists are primarily interested not in the city's auto manufacturing heritage but in its crumbling factories, not in the architectural grandeur of a shuttered church or train station but in the juxtaposition of that grandeur with rubble and ruin. This makes ruin tourism difficult to market from the perspective of local boosters and raises questions about its sustainability. It is also distinct from tourism at ancient ruin sites, common across the world. Where both share attention to the aesthetic of ruin and a fascination with its multiple meanings, the historical distance of ancient societies from their contemporary visitors produces a relationship between the viewer and ruin that is much less concerned with culpability or blame for the production of the ruined landscape. The historical proximity of modern ruins makes them more open to 
interpretations about who is responsible for their existence and enables the guides who narrate them to politicize the conditions of their production.

Just as historical distance distinguishes these practices from ancient ruin tours, social distance distinguishes them from slum or poverty tours (Dovey \& King, 2012; Dürr, 2012; Steinbrink, Frenzel, \& Koens, 2012). While slum tourism is typically practiced by visitors from the Global North in cities of the Global South, the vast majority of visitors to Detroit's ruins are locals or peri-locals, Detroiters themselves or visitors from nearby suburbs. The suburban-city dynamic of these identities is markedly different from the Global North-Global South dynamic of slum tourism with its attendant colonial legacies, raising different questions about ethics and power dynamics, and opening different political possibilities. Finally, ruin tours are distinct from urban exploration (Garrett, 2010) or unguided ruin gazing (Edensor, 2005; Steinmetz, 2008) because they involve tour guides, usually paid, who mediate the tour goers' experience. Therefore, we can examine the discursive significance of ruin tours not only from the perspective of visiting ruin gazers, but also-and in this article, primarily — considering the goals, motivations, and perspectives of the local tour operators.

At the heart of ruin tourism lies a paradox: that such tours represent a form of economic development that takes urban decay as its object. Sites of abandonment therefore take on a dual role; they provide perceived authenticity that attracts visitors, but they also represent the city in a way that developers and city leaders typically do not want to projectthat is, as a failure of industrial modernity. To make sense of this paradox, I make two related arguments. First, ruin tourism can be understood as a mechanism through which the postindustrial city is recapitalized as a site of consumption instead of production, where lofts replace factories and waterfronts turn from shipyards into leisure destinations. However, the ruined landscape of production is not merely replaced by a landscape of consumption, as is typical in processes of creative destruction. Rather, through ruin tours, the abandoned 
landscape of production itself becomes an object of consumption. Second, tour operators do not take urban decay for granted; they do not treat abandoned buildings as a natural part of Detroit's landscape or as aesthetic objects. Instead, they construct place narratives about Detroit that directly confront ruination and suggest different possible responses to urban decay. These responses range from using tours as part of a strategy to attract creative-class workers to the city to using tours as a tool of resistance to racialized dispossession. This suggests that ruin tours do not fit into a singular understanding of either resistance or redevelopment, but that such tourism is an instructive reflection of political struggle about urban place representations and is itself a terrain that struggle.

These arguments emerge from analysis of qualitative data gathered during two months of fieldwork in Detroit in 2012. I participated in eight tours in Detroit, which allowed me to directly observe the exchange of information between guides and tour-goers, shedding light on how tourism operates and how tour operators narrate the place of ruins in Detroit's landscape. I conducted 15 semi-structured interviews with tour planners, guides, and nonprofit leaders involved with the tourism industry in Detroit. ${ }^{i}$ Interviews included questions about the practical aspects of tour operations, the motivations for choosing to showcase some sites over others, and the challenges and opportunities associated with tourism and abandoned infrastructure in Detroit. ${ }^{\text {ii }}$ I examined tour websites and brochures for their rhetoric about different organizations' goals and priorities, comparing these with data gathered through participant observation and interviews. I traced the development of key tour programs in planning and budget documents, news articles, brochures, and press releases; and reviewed income and expenditures reported by tour operators. My inductive analysis of these data explored how tour operators construct place narratives about the city landscape and how these narratives become implicated in broader efforts at redevelopment or resistance. I coded data manually using a combination of in-vivo and open coding and 
validated my theoretical insights with iterative analysis and triangulation across data sources and types.

The sections that follow outline literatures in critical urban geographies on recapitalization and its discursive justifications and provide background to the scale and nature of Detroit's abandonment. In the first of two empirical sections, I provide a history of the development of ruin tours in Detroit in relation to urban redevelopment efforts to recast the city as a site of consumption. In the second, I offer an in-depth analysis of three cases of tours in the city to show how tour operators construct place narratives that suggest different political modes of responding to abandonment and decline in the post-industrial city. I conclude by reflecting on the temporality of ruin tourism and how insights from Detroit can be applied to better understand redevelopment in post-industrial cities across the world.

\section{Consuming the ruined city}

For decades in post-industrial cities across the Global North, the organization of consumption has been replacing the organization of production as the dominant influence on urban development (Massey, 1984; Harvey, 1985, 1989; Zukin 1989, 1991; Smith, 1996). In Harvey's (1989) terms, urban governance has shifted from a managerial stance that focuses on service provision to an entrepreneurial stance that focuses on economic development and job growth, in a process that ties workers' significance more to their role as consumers than to their role as producers of value. Whereas cities used to compete with one another to be centers of manufacturing, they now compete with one another to be centers of consumption (Logan \& Molotch, 1987; Britton, 1991; Cox, 1995). This entails inter-urban competition to host large cultural events (Richards \& Wilson, 2004; Hall, 2006; Schimmel, 2006) and the construction of theme parks, convention centers, entertainment districts, and retail centers to attract visitors and mobile capital (Wrigley \& Lowe, 1995; Kilian \& Dodson, 1996; Scott, 2004). 
In her 1991 book Landscapes of Power, Zukin explores the uneven effects of this shift on urban landscape. She writes,

Place, moreover, is sharply divided between landscapes of consumption and landscapes of devastation. Those places that remain part of a production economy, where men and women produce a physical product for a living, are losers. [...] By contrast, those places that thrive are connected to real estate development, financial exchanges, entertainment — the business of moving money and people—where consumer pleasures hide the reins of concentrated economic control. (p. 5)

As the process advances, landscapes of devastation are transformed into landscapes of consumption if local actors can successfully commodify and sell the industrial past as authentic social capital. "Just as Busch Gardens and Disney World decontextualize the future, Inner Harbor, Faneuil Hall, and South Street Seaport decontextualize the past, turning a landscape of devastation in the inner city into a landscape of consumption," writes Zukin, "At best, when market forces destroy and re-create an existing landscape, its artifacts-like the 110,000-pound cast-iron façade of the Fava Fruit Company in Baltimore - are stored, restored, and even relocated to create an 'authentic' sense of place” (1991, p. 20).

More recent work on the transformation of industrial cities has focused on questions of attracting creative industries and knowledge workers to cities (Florida, 2003, 2005; Peck, 2005; McCann, 2007; Shelton, Zook, \& Wiig, 2014) and on residential transition and gentrification (Lees, 2000; Smith, 2002; Davidson \& Lees, 2005). While this attention to urban transformation and its accompanying displacements is significant, urban geographies of redevelopment often miss an important facet of post-industrial capital accumulation: that of tourism and leisure activities (for an exception, see Herrera, Smith, \& Vera, 2007). This empirical gap has left theoretical absences about the complexity and diversity of strategies for urban recapitalization. 
Another thread of work on urban recapitalization considers its discursive justification through the representations of post-industrial cities as wilderness or wasteland (Smith, 1996). The theme of nature supposedly overtaking cities has been well explored by urban geographers and political ecologists, including in Detroit, to examine how urban nature is alternately portrayed as a sign of neglect and mismanagement or of hopeful rebirth (Gandy, 2013; Millington, 2013). Where redevelopment of supposedly wild urban spaces has not occurred, this narrative of renaturalization has also been used to justify recapitalization through "green infrastructure" projects (Rink, 2009; Safransky, 2014). Literature on urban revitalization has long shown how discursive work to demarcate a place and tie it to particular signifiers is a key part of redevelopment agendas (Jonas \& Wilson, 1999; McCann, 2002, 2004; Bonds, 2013). McCann (2002) calls this the "cultural politics of local economic development," which involve efforts to brand cities or neighborhoods as good places to live and invest. At the same time, studies of urban spatial politics examine how activists and others develop counter-hegemonic discourses of place to advance alternative agendas for collective action (Martin, 2003; DeFilippis \& North, 2004; Wilson \& Grammenos, 2005; Purcell, 2009).

In the case of Detroit, with its metonymic association with Fordism and American capitalism, depictions of the city as a ruined wasteland have prominently circulated, from Camilo Jose Vergara's 1996 essay calling for the establishment of an "American Acropolis" in the city to more recent books of photography (Marchand \& Meffre, 2010; Moore, 2010), documentary films (Temple \& Hencken, 2010; Tillon, Bouthier, \& Fleurantin, 2011; Ewing \& Grady, 2012), and prominent newspaper and magazine stories (Stohr, 2003; Whoriskey, 2011). Cultural studies of these depictions — notably by Herron (1993, 2002, 2013), Steinmetz (2008), and Kinney (2016) — have advanced our understanding of how such images shape conceptions of Detroit in ways that play into broader narratives of white 
nostalgia, racialized decline, and anxiety about economic change. However, cultural studies of circulating images insufficiently reckon with how the discursive power of the image intersects with material practices of urban transformation.

Here, tourism — as a fundamentally discursive practice that also takes place physically in material urban space - is a useful terrain of analysis. I therefore build on these studies to examine the political force of tourism at the scale of the city and argue that tour operators construct place narratives that carry political significance. These place narratives make claims about identity and place meaning, and they work to either contest or reinforce processes of redevelopment in the city. In this way, tourism can have a similar significance to urban politics as other forms of representation — such as public art and graffiti (Dovey, Wollan, \& Woodcock, 2012; McCauliffe, 2012; Donish, 2013) and parades (Regis, 2001; Cohen, 2007; Staeheli, 2008)— that are similarly situated in urban space.

\section{The development of ruin tours in Detroit}

Detroit is an ideal site for this study because of the scale of decline evident in its landscape and because the city's association with the automobile industry gives it a lasting place in the American imagination. While not fundamentally different from other cities (see Robison, 2006), the city's economic, demographic, and infrastructural transitions since the mid- $20^{\text {th }}$ century certainly present many challenges. Following decades of declining manufacturing due to automation and factory relocation, fewer than 100,000 Detroit workers were employed in manufacturing by 2009 , down from over 338,000 in the late 1940 s (Stokan, 2009). Throughout this process of deindustrialization, service sector employment has increased, but not at a rate commensurate with the loss of manufacturing jobs. At the time of fieldwork for this research, unemployment in the city stood at almost 20 percent (U.S. Bureau of Labor Statistics, 2012). This economic shift has been accompanied by a demographic shift of a similar scale. In the second half of the $20^{\text {th }}$ century, Detroit's 
population contracted by half, down from a peak population of 1.9 million, and continued to decline to fewer than 715,000 in 2010 (Boyle, 2001; U.S. Census Bureau, 2012). Much of the outmigration has been to surrounding suburbs. In fact, between 1960 and the early 2000s, the Detroit metropolitan population (including city and suburbs) grew from 3.9 million to 4.4 million. However, without legal authority to annex its suburbs like cities such as Portland or Dallas, the center city has been largely unable to benefit from suburban growth (Gallagher, 2010).

Economic disinvestment and population decline have therefore produced staggering property vacancy. Parts of the city have 60 percent housing vacancy rates (Data Driven Detroit, 2010), and Detroit is home to the world's largest abandoned factory, the Packard Automotive Plant, which covers over 40 acres, along with numerous other abandoned factories, theaters, office buildings, churches, and schools. In the context of its widespread infrastructural decline, Detroit has seen the emergence of a small but significant ruin tour industry, comprising over a dozen tour operations that collectively take thousands of tourgoers to see Detroit's ruins each year (see Figure 1). In some of these tours, ruins are the central focus of the itinerary and narrative; in others, ruins are considered alongside other architectural, cultural, or historical sites. The operations target varying audiences, use different funding structures, include various means of transportation, and operate at different frequencies, but all include some narration of ruins, and all of the tour operators I interviewed consider "the ruins of Detroit" to be a significant attraction for their participants. Questions from other tour-goers on the tours I participated in disproportionately focused on ruin sites, confirming the assessment of the operators. In this section, I draw on archival sources and interviews to trace the development of ruin tours in the city in relation to other efforts to redevelop and recapitalize Detroit. Unlike processes of gentrification or urban renewal, however, I argue that ruin tours represent a recapitalization of the city in which the 
old is not fully replaced by the new but rather becomes the object of a new form of cultural consumption.

The last ten years have seen a significant growth in the quantity and the diversity of Detroit's ruin tour offerings, and over half of the tours considered here were established within just three years of the 2012 fieldwork. This is due to three influences: historical preservation efforts, large-scale cultural events, and a proliferation of media depictions of Detroit's ruins. In the 1990s, cultural tour offerings in Detroit were slim. Preservation Wayne, a historic preservation group started by students at Wayne State University in 1975, offered just a few annual tours as a means of promoting preservation efforts. These tours had an audience that consisted primarily of the organization's members rather than the general public (Preservation Wayne, 1975-2010). In 1993, the organization decided to grow its tour program, and it developed a number of walking tours that have become a core part of its programming efforts. Now, most of the tour-goers are members of the general public, and the organization cites the tour program as an important tool for member recruitment. Preservation Wayne (renamed Preservation Detroit in 2012) continues to operate an extensive tour program and remains one of the largest cultural tour operators in the city. The tours visit a variety of notable architectural sites, including intact and restored sites as well as those in need of restoration or preservation.

Another major influence on the organization of the cultural tourism industry in Detroit came in the early 2000s when two major events - the city's tricentennial celebration in 2001 and Super Bowl XL in 2006 - brought thousands of visitors to the city. The tricentennial celebration included a week of events in July 2001 that attracted over 500,000 people (Wells-Reid, 2001). Preservation Wayne ran a special round of tours to correspond with the celebration and trained dozens of volunteers to act as tour guides during the event. In multiple cases, these volunteers went on to develop their own tour programs. For instance, 
one guide who founded a for-profit tour company noted that his volunteer work at the time of the tricentennial was a major influence in his decision to begin leading tours professionally. Another tour operator also began volunteering as a tour guide for Preservation Wayne before starting her own non-profit tour organization with a business partner who has since started a separate for-profit company.

A large cultural event also catalyzed the founding of Wheelhouse Detroit.

Wheelhouse is a bike shop located in Rivard Plaza on the Detroit River waterfront that offers bike rentals and a variety of guided tours. Karen Gage and Kelli Kavanaugh, owners of Wheelhouse, helped organize the Tour de Troit (a play on the Tour de France) before they opened the shop. Now over 10 years old, Tour de Troit is an annual bike ride in the city that attracted over 5,000 participants in 2012 (Laitner, 2012), and Kavanaugh explained that the growing success of the event in its early years suggested that there was enough cycling interest in the city to sustain a downtown bike shop. Wheelhouse opened in May 2008, and, while tours were originally the least formed part of their business plan, they now make up a quarter of the shop's revenue.

Finally, tour operators attribute the growth of the industry to the proliferation of socalled "ruin porn" in popular media, arguing that it produces interest in the city. Ruin porn includes sets of photographs, written accounts, and other images that depict abandoned buildings as alternately beautiful and repulsive spectacles of past opulence and present failure (Rosenberg, 2011; Millington, 2013). Ruin porn produced in Detroit proliferated in national media after the 2008 economic recession, reflecting a national anxiety about the state of American industry, for which Detroit often serves as a symbolic stand-in. Many of the depictions trod a well-worn circuit of iconic ruins, such as Michigan Central Station, the Lee Plaza Hotel, the Grande Ballroom, and the Packard Plant (see Figure 2), and use equally well-worn tropes, such as the evocation of classical ruins, the suggestion that Detroit is wild 
or returning to nature, and the depiction of the makers of such images as intrepid explorers. Scholars and other writers have criticized ruin porn for aestheticizing poverty, erasing the many people who still live in the city, and failing to account for the socio-economic processes that have created Detroit's ruins (Morton, 2009; Leary, 2011; Millington, 2013).

Critiques of ruin porn abound locally as well, but tour operators also attribute the growth of the city's tourism industry to its proliferation in popular media, arguing that it produces interest in the city. One guide who offers private tours of ruins says of his customers, "They specifically want to see abandoned buildings and ruins - they mention that word." Another says, "They see these pictures, and it's not that different from why do people go to Greece? Why do people go to Egypt? It's a civilization, a past civilization basically.” Many guides understand visitors' curiosity but maintain an ambivalent or even negative view of the attraction to ruins. Jocelyn Ninneman, who co-founded the Detroit Music Tour, explains:

I mean, that's how it all started is when we were young we would go into abandoned buildings and explore things and look for things and take photos, and we even threw parties in them. [...] But at this point, it's been so exploited that we're sick of it, and we feel like Detroit has now moved on from being this murder-and-crime capital and failure-of-economy capital to the ruin porn capital, that is, the ruin porn Disneyland now. [...] Yeah we understand that that's cool and we did it too, but it's the stories behind it that we want to resonate with people.

Thus aware of the paradox of ruin tourism, tour operators tend to view the depictions of Detroit in the media in a dual sense: they inspire interest in the city and motivate visitors to see the city for themselves, and they produce what guides see as a problematic understanding of the city—which guides seek to correct with their tours. 
Throughout the development of the industry, ruin tours have consistently been a part of a process of recapitalizing Detroit. Program operators use tours as a means of generating income, soliciting donations, and encouraging investment in their own programs and in those of businesses and non-profit organizations they work with. Tours bring customers to locally owned restaurants, cafes, and bars, encouraging tour-goers to patronize the businesses, and operators use tours to solicit donations for community organizations whose projects are showcased on tours. Importantly, tour operators view ruins as an essential part of the city's attraction to visitors and do not wish to erase ruins. Instead, ruin tours transform the city into a landscape of consumption in which ruins of old industry are themselves the objects that are consumed. Instead of simply erasing ruins, tours in Detroit urge visitors to confront ruins directly. The following section examines three different ways in which tour operators use these confrontations to narrate Detroit's past, present, and future.

\section{The urban politics of ruin tours: three cases}

While ruin tours always demand some kind of confrontation with ruins, not all tours confront ruins to the same end. Rather, my analysis indicates that different tours suggest different political responses to urban decay. These responses are political in the sense that tour operators not only suggest ways that individual tourists might interpret ruination, but they also suggest different sorts of collective response to the city's ruins. Here I examine three tour operations that construct different place narratives: a pro-business, developmentoriented story of economic rebirth and revitalization; a resistance-focused narration of dispossession and cultural erasure; and a context-heavy story of how present ruins were historically produced. I selected these three cases from the twelve tours operations I examined in detail as the clearest exemplars of the three narrative approaches that emerged from the data. The first two offer different political-economic visions of ruination and redevelopment, while the third involves socio-cultural politics and tries to rework how 
visitors understand the causal processes and material realities of ruin sites. I situate these narratives within the organizational context in which they are shaped before considering the politics they suggest.

\section{Tourism as development: D:hive}

D:hive, which began in 2005 as Inside Detroit, is a nonprofit organization that offered tours as part of a broader strategy of promoting business growth. In 2011, Inside Detroit had an operating budget of approximately $\$ 240,000$, and nearly 80 percent of its revenue came from tours and sales at its welcome center (Internal Revenue Service, 2011). However, in 2012 the organization went through a significant restructuring. One of the founders left to begin a for-profit tour company, while Inside Detroit became part of the Downtown Detroit Partnership (DDP) under a new name, D:hive. ${ }^{\text {iii }}$ DDP is a large public-private partnership whose goals are economic development and physical enhancement of downtown Detroit. Support from DDP allowed the group to offer its public tours free of charge, though donations are still encouraged, and to double tour guides' wages to $\$ 20$ per hour. In addition to these changes in the tour program, D:hive expanded into greater efforts to promote entrepreneurship and encourage creative class workers to settle in Detroit by offering business classes and "Downtown Living" tours that highlight residential development and encourage tour-goers to move to the center city.

I participated in one of D:hive's free downtown walking tours. The tour was led by a young white man who lived in the city but had grown up in the suburbs, and other tour-goers were a white father and teenage daughter from the suburbs and a Pakistani Canadian couple from Windsor, Ontario. The tour began and ended at the D:hive Welcome Center on Woodward Avenue and included stops throughout greater downtown. Empty and ruined buildings were narrated at some of the stops, including, for instance, the Wurlitzer Building, a 14-story Renaissance Revival tower that has stood empty since 1986. In response to 
another tour-goer's question about the status of the building, the D:hive guide lamented the City's inability to convince the owner to maintain it beyond installing a shelter over the sidewalk to protect passersby from terra cotta falling from the façade. Another stop was the old Wayne County Building, a Beaux Arts masterpiece that has been empty only since 2010 and which the couple from Windsor joked with one another that they should buy. In addition to ruins-focused stops, the tour included numerous stops at intact buildings and successful public spaces, including Hart Plaza and the Guardian Building, where the guide pointed out the rare Namibian marble features and Tiffany stained glass clock in the lobby. Towards the end of the tour, the guide briefly told us about downtown residential options, encouraging those on the tour who lived in the metropolitan area to move downtown and informing us of D:hive's resources to help us do so.

In general, the tour presented Detroit's ruins as unfortunate products of historical circumstances that nonetheless gave the city character and presented opportunities for renovation. One D:hive guide said, “In every city, it's the same fancy restaurants, the same chains, the same shops, and there's nothing the same about Detroit. You can't be on autopilot here. [...] The ruins are obviously a big part of that." The tour offered a conventional vision of recapitalization, praising the work of developers such as Dan Gilbert, chairman of Quicken Loans and a major investor in downtown real estate, and highlighting features that might attract creative class workers, including bars, new retail shops, and entertainment venues. This function of the tours to make the city attractive to potential residents was made explicit by one guide I interviewed:

We're not going to fix the public schools overnight, and we're not going to fix crime overnight. But what we can do overnight is inform people about what's happening now, that it isn't dangerous everywhere, that there are some good public schools. That 
people are moving here. That there's new things going on. [...] That's the biggest point, that it's really great here. Honestly, I want them to be a little jealous.

Tourism in this mode is a way of affirming redevelopment and attempting to attract creative class workers to the city, even as it accepts ruins as an inevitable feature of the city's landscape for the foreseeable future. As D:hive has grown and come under the auspices of the Downtown Detroit Partnership, adding business classes and real estate tours, economic development has become a more prominent aspect of its agenda. The tour narrative of excitement and possibility supplements a broader vision of conventional recapitalization in Detroit.

\section{Tourism as resistance: Detroit Music Tour}

The Detroit Music Tour is a collaborative effort of Jocelyn Ninneman of Pont:Productions and Carleton Gholz of the Detroit Sound Conservancy. Ninneman had been working on developing a Detroit music tour since 2003, but it was not until 2012 that circumstances came together sufficiently to run a pilot at the Allied Media Conference (AMC), which takes place in Detroit each June. As part of the AMC, the tour was funded through registration fees and offered at no additional cost to attendees. ${ }^{\text {iv }}$ Those who went on the tour reflected the makeup of the conference: majority people of color, youth-oriented but representing a spread of ages, and including activists, media-makers, and researchers. Traveling by bus, the tour included stops around the city's central neighborhoods, including the Motown recording studio (now a museum), the former site of Ruth Ellis's ${ }^{\mathrm{v}}$ home (now an empty lot), and United Sounds Systems (a still functioning recording studio). It also included a drive through what remains of the neighborhood once known as Paradise Valley, historically the entertainment district of the city's black population, which was demolished in the 1960 s to make way for Interstate-75, which runs to downtown from Detroit's northern suburbs. 
While the tour visits sites both active and inactive, Ninneman and Gholz are very careful about how they narrate ruins on the tour. "One of the worries that we had, that I always have, is that it's very easy for this tour, or for any tour in Detroit really, to quickly slip into a ruin porn tour," said Ninneman. Gholz also mentioned ruin porn, saying:

I think that's the biggest concern we have is how do we attempt to complicate that conversation without lying about how bad things are, right, because shit's bad. So you've got to be honest, don't want to lie to people, but clearly we don't believe that just theories or pictures of ruins are encompassing of where Detroit is at, or [are] interesting, frankly.

Ninneman and Gholz are very up front in their criticism of urban renewal policies and other political economic forces that produced the landscape visible in the city, and they discuss racism, dispossession, and gentrification directly. The narration of sites that are not only abandoned but in fact removed from the landscape is also a challenge. Said Gholz, "How do you stand in an empty field and go, 'Something was really important here'? Now in the $21^{\text {st }}$ century, with certain kinds of technologies and iPhones and some of these things, you can sort of get around some of this stuff, [...] but the empty lot is very hard to narrate." Including empty lots and shuttered theaters alongside extant recording studios and other still-operating sites as they do allows them to acknowledge the devastation wrought by urban renewal, particularly against communities of color, and to recognize the significance of sites that have not survived to Detroit's resilient and still-active music communities.

The politics of how Detroit is represented and by whom are particularly important in this effort. Ninneman, a Detroit native who now lives in New Orleans, cites the "disaster and devastation tours" that appeared in New Orleans after Hurricane Katrina as an important influence on the development of the music tour. She describes residents of a New Orleans neighborhood in 2005: 
They're just doing whatever it is they need to do on their property, and then there's busloads of people coming down and taking pictures of them, like they're animals at a zoo. Obviously that bothers me. [...] It made me think about every little detail of a cultural tour, because as soon as you have a busload of outsiders coming through someone's neighborhood to take pictures and learn about that neighborhood but the people that actually live in that neighborhood are not a part of that tour, that's a problem.

As a result, the music tour relies on griots, or storytellers, who are or were active in Detroit's music scenes to ride along on the bus and to narrate the sites from personal experience. Said Ninneman, "We would prefer to get the griots to tell the story [...] because it's in their words, from their mouths, and they're getting the credit and recognition for it." Broadening and complicating the stories told about Detroit is a key goal of the tour, and incorporating many voices in the actual narration of sites in this way is a key strategy.

Their goals for the tour include the preservation of important music landmarks, as well as preservation of diverse stories from those who have made up Detroit's many important music scenes. Ninneman and Gholz seek to complicate the flat narratives that national media often tell about Detroit. Said Gholz, "I want to tell a multiplicity of stories and let people find themselves in the richness of those stories and have them make some decisions and think." Their target audience is as much Detroiters themselves as it is outside visitors. Coming out of Detroit's techno scene, Ninneman has marketed Detroit music abroad and knows that there's an eager audience for the city's music and music history among fans outside the region. However, she says, "What's really important to me personally and emotionally is the fact that Detroit doesn't even really respect itself and that Detroiters don't even know just how talented or renowned their own next door neighbors are.” In trying to give resident tour-goers a more positive sense of self and place, the tour suggests a politics of 
empowerment of diverse actors within the city to confront the violence of urban renewal on the city's communities and landscapes.

Like D:hive, Ninneman and Gholz see tourism as a potential site of economic development, but they are wary that corporations, and not members of Detroit's music community, might see the most gains. Says Ninneman, "They [corporations] get the value, they see the value in Detroit's music legacy before most Detroiters do. And I worry that those entities are going to monopolize on our music legacy and capitalize on it and own it, and that's going to be a problem." By incorporating griots as narrators of different sites, the tour allows community members to drive tour development and positions them to be beneficiaries of recognition and, if the tour eventually becomes profitable, of profits. The recapitalization that the Detroit Music Tour suggests is therefore one of community controlled redevelopment.

\section{Tourism as liminal educational project: DetroitUrbex}

DetroitUrbex is a different sort of tour organization than D:hive or the Detroit Music Tour. The owner, "Steve," fir first began exploring Detroit's abandoned buildings on his own as a photographer. Living in Ohio, he offered tours to acquaintances who would give him rides to the city when his car was broken down and realized it was something people would pay him for. By 2012, he lived in Detroit and made the majority of his income giving tours. In 2011, his first year of operation, he gave nearly 40 tours, and by July 2012, he was on track to double that number in his second year of operation. His rates vary, but in 2012 a typical half-day tour for 1-3 people cost $\$ 150$, while a full day (up to 10 hours) cost $\$ 200$. Most of Steve's customers are photographers or researchers, including academics, journalists, fiction writers, and filmmakers. While he has customers from all over the world, Steve estimates that the majority of people he guides are suburbanites from metropolitan Detroit. Most are also white, as is Steve. The company's website includes a brief and 
standard description of DetroitUrbex's tours, but it does not provide a price schedule, reviews from previous customers, or a contact name beyond a generic site administrator email address. Steve says this is deliberate:

There's a very passive vetting process that comes when somebody contacts me for a tour. It's a little unusual, but the first thing is I don't immediately give people a name. I almost never give them a name until the day before, the day of, or when we're shaking hands when we meet. That's deliberate. It's not just to protect my privacy. [...] It takes a leap of faith, and that weeds out a lot of the voyeurs or gawkers. Steve estimates that only half of those who contact him for tours make it past this first stage of vetting, and if potential customers insist on seeing only "the bad stuff," he turns them away. In this way, Steve recognizes the role of the tourist in the production of knowledge on a tour. He may not be able to fully control the representations his customers produce about the city, but by vetting customers in advance, he attempts to weed out those who he believes are uninterested in a more complicated understanding of the city's landscape than that offered in ruin porn.

A typical tour with DetroitUrbex is an all-day affair. The guide meets customers for breakfast at Duly's Place in Southwest Detroit, where a plate of eggs, toast, and bacon sells for $\$ 2.75$, cash only. The customer provides transportation, with the guide riding in the passenger seat to give directions and narrate the scene. Steve tailors tours to the customers' interests, offering options about what sites to visit and making the itinerary flexible and dynamic. While Steve's customers are primarily interested in seeing ruins, his itineraries also include stops that illustrate the more vibrant side of the city. Our tour took us into the fabulous Guardian Building, past the Belle Isle Aquarium, and to the sculpture yard near MBAD African Bead Museum. These non-ruin sites showcase the city's architectural and 
cultural value, acting as a counter to sites such as moldering churches, shuttered schools, and empty factories.

Despite an opening set of ground rules that warned me to not run from police and to let Steve do the talking if we were confronted by anyone inside of a building, we saw few people at the ruin sites other than scrappers at work in the Packard Plant, a yard crew mowing lawns at an empty high school, and a handful of neighbors. Entering buildings involved intimate knowledge of many of the sites but was generally not physically difficult; however, the uneven terrain and frequent necessity to climb over debris does generally limit the DetroitUrbex audience to those who are able-bodied. Nearly every site showed signs of frequent visitors: piles of garbage were common, missing tile or woodwork had been taken for souvenirs or resale, and spray paint covered most vertical surfaces. Many places smelled of recent fires or damp, crumbling plaster.

Steve's narration of the sites was wide-ranging. He discussed the physical processes that contribute to a building's collapse; recited architects' names, ownership histories, and factory production statistics; and recreated a sense of the buildings in their heydays with the help of historic photos on his cell phone and stories from his archival research. In total, the tour lasted about 8 hours. Steve says about his goal:

What history is out there tends to fall into the same narrative. It's a blame game, like blame the autoworkers, blame the migrants, blame a certain race or ethnicity for all the problems of the city, blame the government, blame the people who left. Because that's easier to digest. [...] What's harder to accept is that there is no particular thing that caused the city to get where it's at today. There's a lot of small factors and a lot of really huge things that happened. It's very complicated. [...] If they don't have any experience with the city, what they see is going to blow their mind. Maybe not for the better, but it's definitely going to challenge the way that they think. 
The project of DetroitUrbex's tours in this sense is one of thick contextualization, meant to counter the flimsy aestheticization of ruins offered by ruin porn. Steve challenges tour-goers not to move to Detroit and be part of its revitalization but to understand the complex socioeconomic processes that have produced its present ruins and how those processes affect the city's residents.

Whereas the first two cases examined here offer different political-economic visions of future development in which tourism itself can play a role, Steve sees his work as a liminal project. He said, “I would love it if my job disappeared. I'm glad every time a building is saved, every time that I lose a location to processes that are good. That's a victory in my eyes, and I'll gladly accept those." In this way, Steve prioritizes the educational aims of his tours over business sustainability or landscape preservation and acknowledges the likely liminal nature of tourism that takes ruination as its object. The politics suggested by DetroitUrbex is therefore geared towards the present moment instead of the future; it is a socio-cultural project that aims to rework how visitors understand the causal processes and material realities of urban ruination.

\section{Conclusion}

Industrial ruins are not unique to Detroit. Furthermore, while Detroit has a particularly robust ruin tour scene, evidence of similar practices exists at sites across the globe (Edensor, 2005; Hell \& Schönle, 2010; Fraser, 2012). In this article I seek to understand how the growth of tours showcasing industrial ruins is related to broader practices of urban redevelopment. As a mechanism of capital accumulation, tourism is a vital process to study for urban scholars seeking to understand consumption and the city, and the discourses of tour narratives further provide insight into how local actors advance and contest different arguments about space, place, and community in the face of urban change. 
In the case of Detroit, ruin tours are growing due to a combination of efforts to develop the city as a tourist destination and of media attention in the wake of the Great Recession that highlighted Detroit as a city of iconic ruins. It can be understood as part of the process of recapitalizing the city as a site of consumption instead of production. However, this study indicates that the ruined landscape of production is not merely replaced by the landscape of consumption through gentrification or urban renewal, but that the ruined landscape of production itself becomes an object of touristic consumption. Thus, in examining ruin tours, we see that recapitalization of the city can take more diverse forms than previously considered. I argue that this is particularly significant since these diverse forms of recapitalization open equally diverse possibilities for political responses to urban change.

However, ongoing pressures to recapitalize cities in ways that do replace ruined landscapes with new development raise questions about the temporality of ruin tourism and its long-term sustainability. Indeed, as developments like a new arena that opened just north of downtown in 2017 have increased pressures to project an image of Detroit as safe and welcoming to visitors, owners of the city's iconic ruins have been pressured to increase security and move forward with plans to redevelop many of the sites. Ruin tours may therefore be a liminal practice in Detroit and cities like it, soon to be replaced by more traditional cultural heritage tourism and sites of recreational consumption. Nonetheless, the narratives that surround ruined industrial landscapes offer important clues about how redevelopment unfolds in post-industrial cities, including the diverse ways local actors use ruins to understand past, present, and future struggles over belonging and self-representation. My analysis of the place narratives put forward in ruin tours uncovers two tours that articulate visions for redevelopment in Detroit that center on political-economic dimensions of its material landscape, albeit in different ways. While the D:hive tour advanced a vision of 
conventional redevelopment driven by creative class workers, the Detroit Music Tour envisioned community-controlled redevelopment that prioritizes the needs of long-term residents and attends to histories of dispossession and cultural erasure. The third tour adopts a socio-cultural approach. Explicitly countering ruin porn, the DetroitUrbex tour attempts to contextualize visitors' understandings of present ruination instead of offering a vision of the future. Insofar as the impoverishment of people and places happens through both politicaleconomic and socio-cultural processes (Lawson, 2012), these three tours together speak to multiple dimensions of the city's impoverishment. Yet, explicitly and implicitly, they call for different processes of redevelopment, with differing implications for community control of the social, political, and economic terms of Detroit's future urban geographies. This analysis demonstrates that ruin tours, while thus far a largely unexplored phenomenon in urban geographic research, provide key insights into the politics of place representation and urban redevelopment in post-industrial cities. 


\section{References}

Bonds, Anne (2013). Economic development, racialization, and privilege: "Yes in my backyard" prison politics and the reinvention of Madras, Oregon. Annals of the Association of American Geographers, 103(6), 1389-1405.

Boyle, Kevin (2001). The ruins of Detroit: Exploring the urban crisis in the Motor City. Michigan Historical Review, 27, 109-127.

Britton, Stephen (1991). Tourism, capital and place: towards a critical geography of tourism. Environment and Planning D: Society and Space, 9(4), 451-478.

Cohen, Shaul (2007). Winning while losing: the apprentice boys of Derry walk their beat. Political Geography, 26(8), 951-967.

Cox, Kevin R. (1995). Globalisation, competition and the politics of local economic development. Urban studies, 32(2), 213-224.

Data Driven Detroit. (2010). Housing vacancy rate by Census block group, Detroit, Michigan [map]. Retrieved from http://datadrivendetroit.org/wpcontent/uploads/2010/04/HsgVacRateBG.pdf

Davidson, Mark, \& Lees, Loretta (2005). New-build 'gentrification'and London's riverside renaissance. Environment and planning A, 37(7), 1165-1190.

Detroit Tourism Board's 'hidden Detroit' campaign results in 24 deaths. (2004, October 7). The Onion. Retrieved from https://www.theonion.com/detroit-tourism-boards-hiddendetroit-campaign-results-1819567581

DeFilippis, James, \& North, Peter (2004). The emancipatory community? Place, politics, and collective action in cities. In Loretta Lees (Ed.), The Emancipatory City? Paradoxes and Possibilities (pp. 72-90). London: SAGE.

Donish, Cassie (2013). Geographies of art and urban change: Contesting gentrification through aesthetic encounters in San Francisco's Mission District (Master's thesis). University of Oregon, Eugene, OR. Retrieved from https://scholarsbank.uoregon.edu/xmlui/bitstream/handle/1794/13323/Donish_oregon _0171N_10758.pdf

Dovey, Kim, \& King, Ross (2012). Informal urbanism and the taste for slums. Tourism Geographies, 14, 275-293.

Dovey, Kim, Wollan, Simon, \& Woodcock, Ian (2012). Placing graffiti: creating and contesting character in inner-city Melbourne. Journal of Urban Design, 17(1), 21-41. 
Dürr, Eveline (2012). Urban poverty, spatial representation, and mobility: Touring a slum in Mexico. International Journal of Urban and Regional Research, 36(4), 1468-2427.

Edensor, Tim (2005). Industrial ruins: spaces, aesthetics and materiality. New York, NY: Berg.

Ewing, Heidi, \& Grady, Rachel (Directors). (2012). Detropia [Documentary film]. USA: Loki Films.

Florida, Richard L. (2003). The rise of the creative class: And how it's transforming work, leisure, community and everyday life. New York, NY: Basic Books.

Florida, Richard L. (2005). Cities and the creative class. New York: Routledge.

Fraser, Emma (2012). Urban exploration as adventure tourism. In Hazel Andrews \& Les Roberts (Eds.), Liminal landscapes: Travel, experience and spaces in-between (pp. 136-150). New York, NY: Routledge.

Gallagher, John (2010). Reimagining Detroit: Opportunities for redefining an American city. Detroit, MI: Wayne State University Press.

Gandy, Matthew (2013). Marginalia: Aesthetics, ecology, and urban wastelands. Annals of the Association of American Geographers, 103(6), 1301-1316.

Garrett, Bradley L. (2010). Urban explorers: Quests for myth, mystery and meaning. Geography Compass, 4(10), 1448-1461.

Hall, C. Michael (2006). Urban entrepreneurship, corporate interests and sports mega-events: The thin policies of competitiveness within the hard outcomes of neoliberalism. The Sociological Review, 54(s2), 59-70.

Harvey, David (1985). The urbanization of capital: Studies in the history and theory of capitalist urbanization. Baltimore, MD: Johns Hopkins University Press.

Harvey, David (1989). From managerialism to entrepreneurialism: The transformation in urban governance in late capitalism. Geografiska Annaler, 71(1), 3-17.

Hell, Julia, \& Schönle, Andreas. (Eds.). (2010). Ruins of modernity. Durham, NC: Duke University Press.

Herrera, Luz Marina García, Smith, Neil, \& Vera, Miguel Ángel Mejías (2007). Gentrification, displacement, and tourism in Santa Cruz de Tenerife. Urban Geography, 28(3), 276-298.

Herron, Jerry (1993). AfterCulture: Detroit and the humiliation of history. Detroit, MI: Wayne State University Press.

Herron, Jerry (2002). Three meditations on the ruins of Detroit. In Georgia Daskalakis, Charles Waldheim, and Jason Young (Eds.), Stalking Detroit. Barcelona: Actar-D. 
Herron, Jerry (2013). Motor City breakdown: Detroit in literature and art. Places Journal. Retrieved from https://placesjournal.org/article/motor-city-breakdown/

Internal Revenue Service, U.S. Dept. of Treasury. (2011). 2011 return of organization exempt from income tax (Form 990): Inside Detroit. Guidestar. Retrieved from http://www.guidestar.org/FinDocuments/2011/593/842/2011-593842451-087845039.pdf

Jonas, Andrew E. G., \& Wilson, David (1999). The city as a growth machine: critical reflections two decades later. In Andrew E. G. Jonas, \& David Wilson (Eds.), The urban growth machine: Critical perspectives two decades later (pp. 3-18). Albany, NY: State University of New York Press.

Kilian, Darryll, \& Dodson, Belinda J. (1996). Forging a postmodern waterfront: Urban form and spectacle at the Victoria and Alfred Docklands. South African Geographical Journal, 78(1), 29-40.

Kinney, Rebecca (2016). Beautiful wasteland: The rise of Detroit as America's postindustrial frontier. Minneapolis, MN: University of Minnesota Press.

Laitner, Bill. (2012, September 15). Tour de Troit bike ride breaks all records. Detroit Free Press. Retrieved from http://www.freep.com/article/20120915/NEWS01/120915036/Tour-de-Troit-bikeride-breaks-all-records

Lawson, Victoria (2012). Decentering poverty studies: Middle class alliances and the social construction of poverty. Singapore Journal of Tropical Geography, 33(1), 1-19.

Leary, John Patrick (2011, January 15). Detroitism. Guernica. Retrieved from http://www.guernicamag.com/features/leary_1_15_11/

Lees, Loretta (2000). A reappraisal of gentrification: Towards a "geography of gentrification." Progress in Human Geography, 24(3), 389-408.

Logan, John R., \& Molotch, Harvey Luskin (2007). Urban fortunes: The political economy of place. Berkeley, CA: University of California Press.

Marchand, Yves, \& Meffre, Romain. (2010). The ruins of Detroit. London: Steidl.

Martin, Deborah G. (2003). "Place-framing” as Place-making: Constituting a neighborhood for organizing and activism. Annals of the Association of American Geographers, 93(3), 730-750.

Massey, Doreen B. (1984). Spatial divisions of labour: Social structures and the geography of production. London: Macmillan. 
McCann, Eugene J. (2002). The cultural politics of local economic development: Meaningmaking, place-making, and the urban policy process. Geoforum, 33(3), 385-398.

McCann, Eugene J. (2004). "Best places": Interurban competition, quality of life and popular media discourse. Urban Studies, 41(10), 1909-1929.

McCann, Eugene J. (2007). Inequality and politics in the creative city-region: Questions of liveability and state strategy. International Journal of Urban and Regional Research, $31(1), 188-196$.

McAuliffe, Cameron (2012). Graffiti or street art? Negotiating the moral geographies of the creative city. Journal of Urban Affairs, 34(2), 189-206.

Millington, Nate (2013). Post industrial imaginaries: Nature, representation, and ruin in Detroit, Michigan. International Journal of Urban and Regional Research, 37(1), 279-296.

Moore, Andrew (2010). Detroit Disassembled. Akron, OH: Damiani.

Morton, Thomas (2009). Something, something, something, Detroit. Vice. Retrieved from http:/www.vice.com/read/something-something-something-detroit-994-v16n8

Peck, Jamie (2005). Struggling with the creative class. International Journal of Urban and Regional Research, 29(4), 740-770.

Preservation Wayne (1975-2010). Preservation Wayne Records, Box 4, Folders 21-27. Archives of Labor and Urban Affairs. Wayne State University, Detroit, MI.

Purcell, Mark (2009). Resisting neoliberalization: Communicative planning or radical democratic movements? Planning Theory 8(2), 140-165.

Regis, Helen A. (2001). Blackness and the politics of memory in the New Orleans second line. American Ethnologist, 28(4), 752-777.

Richards, Greg, \& Wilson, Julie (2004). The impact of cultural events on city image: Rotterdam, cultural capital of Europe 2001. Urban Studies, 41(10), 1931-1951.

Rink, Dieter (2009). Wilderness: The nature of urban shrinkage? The debate on urban restructuring and restoration in Eastern Germany. Nature and Culture, 4(3), 275-292.

Robinson, Jennifer (2006). Ordinary cities: Between modernity and development. London: Routledge.

Rosenberg, Eli (2011, January 20). Motown or ghostown? Ruin porn in Detroit. The Atlantic Wire. Retrieved from

http://www.theatlanticwire.com/entertainment/2011/01/motown-or-ghostown-ruinporn-in-detroit/21443/ 
Safransky, Sara (2014). Greening the urban frontier: Race, property, and resettlement in Detroit. Geoforum, 56, 237-248.

Schimmel, Kimberly S. (2006). Deep play: Sports mega-events and urban social conditions in the USA. The Sociological Review, 54(s2), 160-174.

Scott, Allen J. (2004). Cultural-products industries and urban economic development prospects for growth and market contestation in global context. Urban Affairs Review, 39(4), 461-490.

Shelton, Taylor, Zook, Matthew, \& Wiig, Alan (2014). The "actually existing smart city." Cambridge Journal of Regions, Economy and Society, 8(1), 13-25.

Smith, Neil (1996). The new urban frontier: Gentrification and the revanchist city. New York, NY: Routledge.

Smith, Neil (2002). New globalism, new urbanism: Gentrification as global urban strategy. Antipode, 34(3), 427-450.

Staeheli, Lynn A. (2008). Political geography: Difference, recognition, and the contested terrains of political claims-making. Progress in Human Geography, 32(4), 561-570.

Steinbrink, Malte, Frenzel, Fabian, \& Koens, Ko (2012). Development and globalization of a new trend in tourism. In Fabian Frenzel, Ko Koens and Malte Steinbrink (Eds.), Slum tourism: Poverty, power, and ethics (pp. 1-18). New York, NY: Routledge.

Steinmetz, George (2008). Harrowed landscapes: White ruingazers in Namibia and Detroit and the cultivation of memory. Visual Studies, 23(3), 211-237.

Stohr, Kate (2003, December 4.) In the capital of the car, nature stakes a claim. The New York Times. Retrieved from http://www.nytimes.com/2003/12/04/garden/in-thecapital-of-the-car-nature-stakes-a-claim.html

Stokan, Eric (2009). The decline of Detroit manufacturing. Wayne State University Center for Urban Studies. Retrieved from http://econdev.cus.wayne.edu/blog/post/thedecline-of-detroit-manufacturing.aspx

Temple, Julien (Director), \& Hencken, Georgia (Producer). (2010). Requiem for Detroit? [Television documentary]. United Kingdom: BBC.

Tillon, Florent (Director), Bouthier, Bernard (Producer), \& Fleurantin, Pierre-Emmanuel (Producer). (2011). Detroit, Ville Sauvage [Documentary film]. France: Ego Productions.

U.S. Bureau of Labor Statistics. (2012). Local unemployment statistics: Detroit, MI. Retrieved from http://data.bls.gov/ 
U.S. Census Bureau. (2012). State \& county quickfacts: Detroit (city), MI. Retrieved from http://quickfacts.census.gov/qfd/states/26/2622000.html

Vergara, Camilo José (1996). American Acropolis. New Statesman \& Society, 9(385): 16-19.

Wells-Reid, Elliott (2001, July 22). Tricentennial celebration. The Michigan Daily. Retrieved from http://www.michigandaily.com/content/tricentennial-celebration

Whoriskey, Peter. (2011, January 29). Among the ghosts of Detroit. The Washington Post. Retrieved from http://www.washingtonpost.com/opinions/among-the-ghosts-ofdetroit/2011/01/28/ABrE8LE_story.html

Wilson, David, \& Grammenos, Dennis (2005). Gentrification, discourse, and the body: Chicago's Humboldt Park. Environment and Planning D: Society and Space, 23(2), 295-312.

Wrigley, Neil, \& Lowe, Michelle (1996). Retailing, consumption and capital: Towards the new retail geography. Essex: Longman Group.

Zukin, Sharon (1982). Loft living: Culture and capital in urban change. Baltimore, MD: Johns Hopkins University Press.

Zukin, Sharon (1991). Landscapes of power: from Detroit to Disney World. Berkeley, CA: University of California Press. 
Figure 1. Timeline of ruin tour development.

Figure 2. Map of iconic ruin sites. Black dots indicate iconic ruin sites and gray dots indicate other Detroit landmarks. The central business district is identified by the gray polygon.

\footnotetext{
${ }^{\mathrm{i}}$ Most interviews took place in-person. Two were conducted by telephone and one by video chat.

${ }^{\text {ii }}$ Some interviewees asked to be identified by their names, while others preferred pseudonyms. Pseudonyms are identified as such on first use.

iii In 2015, D:hive underwent another reorganization, as its tour and welcome center were rebranded as Detroit Experience Factory and its business development program became the Build Institute. It remains under the DDP.

${ }^{\text {iv }}$ I participated in this tour in 2016, rather than in 2012 when the rest of the fieldwork was conducted. In order to correct for ways the tour narrative may have changed in those four years, my analysis also draws on data collected in 2012 about the tour at that time, including the 2012 pre-tour introduction and information about the tour that was drawn from interviews and textual and photo documentation produced by tour participants and collected in the online session notes commonly produced for conference sessions at the AMC that are made available to AMC participants through the conference website.

${ }^{v}$ Ellis (1899-2000) was the first black woman to own a printing company in Detroit. The parties she threw at her home were an important feature of the Detroit music and gay cultural scenes in the mid- $20^{\text {th }}$ century.

${ }^{\text {vi }}$ A pseudonym.
} 
Figure 1. Timeline of ruin tour development.

\begin{tabular}{ll}
\hline Date & \multicolumn{1}{c}{ Tour Program } \\
\hline Early & Preservation Wayne (now Preservation \\
1990 s & Detroit) \\
1997 & Fabulous Ruins of Detroit virtual tour \\
2001 & Sierra Club-Detroit Environmental Justice \\
& tour \\
2004 & Detroit Tour Connections \\
2005 & Inside Detroit (now D:hive) \\
2007 & Feet on the Street \\
2008 & Wheelhouse Detroit \\
2011 & Segways2u \\
2011 & Detroit Urbex \\
2012 & Detroit Urban Adventures \\
2012 & Show Me Detroit \\
2012 & Detroit Music Tour \\
\hline
\end{tabular}


Figure 2. Map of iconic ruin sites. Black dots indicate iconic ruin sites and gray dots indicate other Detroit landmarks. The central business district is identified by the gray polygon.

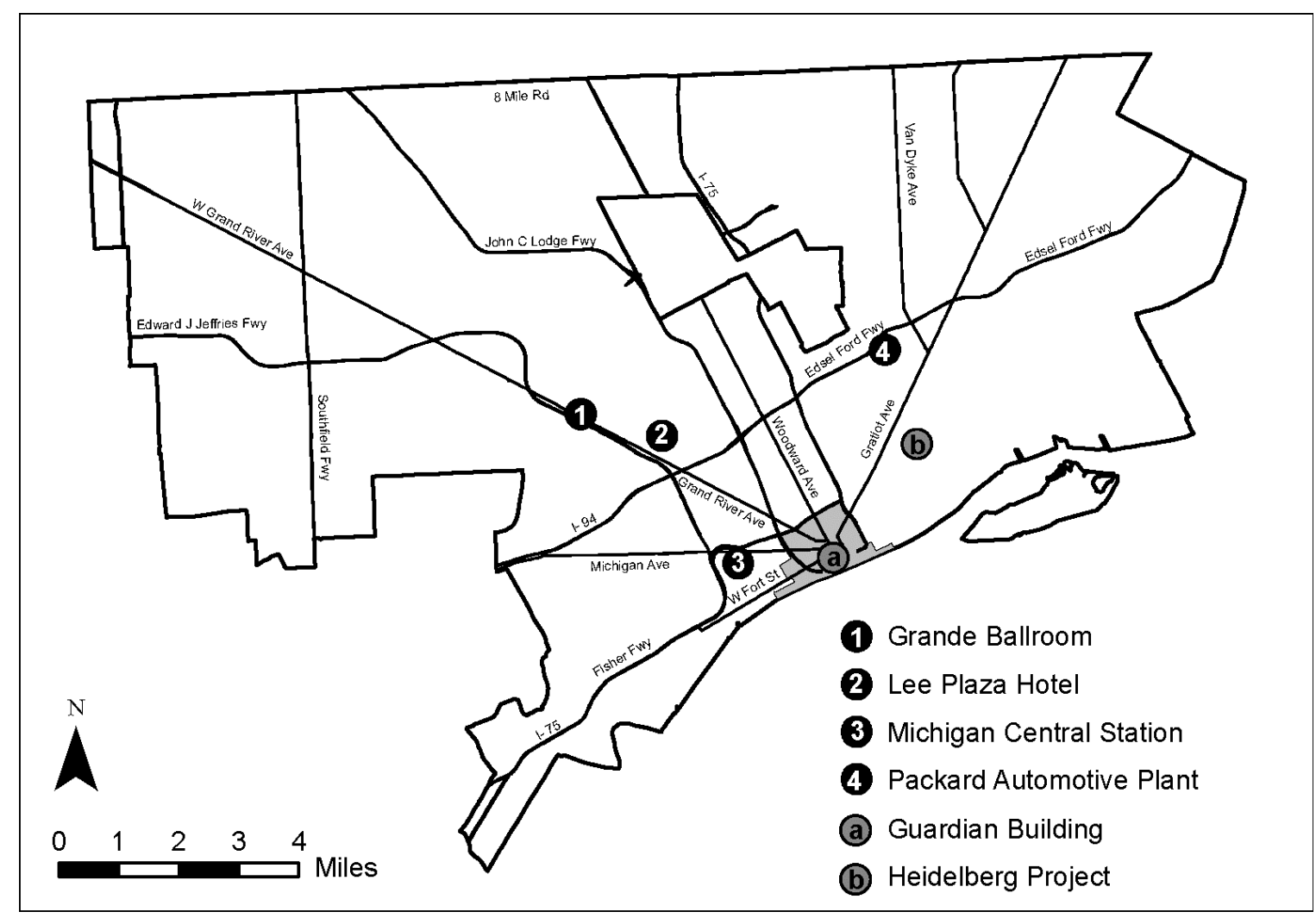

